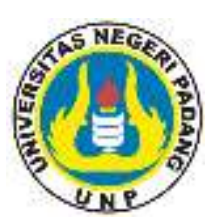

\title{
PENGUASAAN KANOUKEI MAHASISWA TAHUN MASUK 2018 PROGRAM STUDI PENDIDIKAN BAHASA JEPANG UNIVERSITAS NEGERI PADANG
}

\author{
Meza Runa Desmita ${ }^{1}$, Meira Anggia Putri ${ }^{2}$ \\ Program Studi Pendidikan Bahasa Jepang ${ }^{1}$ (Jurusan Bahasa dan Sastra Inggris, Fakultas \\ Bahasa dan Seni, Universitas Negeri Padang) \\ Program Studi Pendidikan Bahasa Jepang 2 (Jurusan Bahasa dan Sastra Inggris, Fakultas \\ Bahasa dan Seni, Universitas Negeri Padang) \\ Email Penulis : mezarunaa@gmail.com
}

\begin{tabular}{ll}
\hline \multicolumn{3}{l}{ Sejarah Artikel } \\
\hline Submit $: 2020-05-05$ \\
Diterima : $2020-06-18$ \\
Diterbitkan $: 2020-07-20$
\end{tabular}

\section{Kata Kunci:}

Keigo, sonkeigo, kenjougo, teineigo, factors that influence keigo.

\begin{abstract}
Abstrak
This study discusses the mastery of kanoukei in 2018 students of Japanese language study programs at Padang State University. The purpose of this study was to determine the kanoukei mastery of 2018 students entering the Japanese Language Study Program at Padang State University. This type of research used in this research is quantitative research with descriptive methods. The population in this study were students entering 2018 Japanese Language Education Study Program, Padang State University, amounting to 62 people. The sample in this study amounted to 30 people. The data of this study are the kanoukei mastery test scores for 2018 students entering the Japanese Language Study Program at Padang State University. Based on the results of the research carried out it can be concluded that the mastery of student kanoukei in 2018 in general is in the qualification "more than enough" with an average of 60.43 .
\end{abstract}

\section{PENDAHULUAN}

Bahasa merupakan alat yang digunakan untuk berinteraksi dalam kehidupan bagi manusia. Bahasa berfungsi untuk menyampaikan perasaan dan pikiran seseorang kepada orang lain, baik berupa lisan, tulisan maupun berupa isyarat. Menurut Sutedi (2011:2), ketika kita menyampaikan ide, pikiran, gagasan, hasrat, dan keinginan kepada seseorang baik secara lisan maupun tulisan, orang tersebut dapat menangkap apa yang kita maksud, tiada lain karena ia memahami makna yang dituangkan melalui bahasa tersebut. Jadi, fungsi bahasa merupakan media untuk menyampaikan suatu makna kepada seseorang baik secara lisan maupun tertulis.

Pada era globalisasi kita tidak hanya harus mahir menggunakan bahasa ibu, tetapi juga harus mempelajari bahasa asing, salah satunya adalah bahasa Jepang. Bahasa Jepang merupakan bahasa yang unik. Sebagaimana Sudjianto dan Dahidi mengatakan bahwa keunikan bahasa Jepang dapat dilihat dari huruf dan tata bahasa yang berbeda dari bahasa negara lain. Bahasa Jepang juga memiliki karakteristik

\footnotetext{
${ }^{1}$ Mahasiswa Prodi Pendidikan Bahasa Jepang FBS UNP Iulus pada Desember 2019

2 Dosen Prodi Pendidikan Bahasa Jepang FBS UNP
} 
tersendiri yang membedakannya dengan bahasa lain. Karakteristik tersebut dapat diamati dari huruf, kosakata, sistem pengucapan, gramatikal dan ragam bahasanya.

Menurut Sudjianto (2009:148), kelas kata dibagi menjadi dua bagian besar yakni jiritsugo dan fuzokugo. Jiritsugo adalah kelas kata yang dengan sendirinya dapat menjadi sebuah frase seperti meishi 'nomina', doushi 'verba', keiyoushi atau ada juga yang menyebutnya na-keiyoushi 'adjektiva na', fukushi 'adverbia', rentaishi 'prenomina', setsuzokushi 'konjungsi', dan kandoushi 'interjeksi', sedangkan fuzokugo adalah kelas kata yang dengan sendirinya tidak dapat menjadi frase seperti kelas kata joshi 'partikel' dan jodoushi 'verba bantu'.

Di dalam kelompok jiritsugo ada kata-kata yang dapat mengalami perubahan bentuk dan ada juga kata-kata yang tidak dapat mengalami perubahan. Di dalam fuzokugo pun ada kelas kata yang dapat mengalami perubahan dan ada juga yang tidak dapat mengalami perubahan. Kata-kata yang dapat mengalami perubahan disebut jodoushi, sedangkan kata-kata yang tidak mengalami perubahan disebut joshi. (Sudjianto, 2009:149).

Sudjianto dan Dahidi (2009: 174) Jodoushi merupakan kelas kata yang dapat berubah bentuk berdasarkan fungsi kata tersebut dalam konteks tertentu . Misalkan dalam kalimat 私は朝起きられる (watashi wa asa okirareru) yang berarti “Saya dapat bangun pagi dengan cepat". Pada kalimat tersebut terdapat kata okirareru yang terdiri dari akar kata okiru yang berarti " bangun", dan jodoushi berbentuk rareru yang mengidentifikasikan bahwa kata tersebut menerangkan kemampuan untuk melakukan pekerjaan atau aktifitas.

Berdasarkan Jidoo Gengo Kenkyuukai (dalam Sudjianto dan Dahidi, 2009: 174-180), Jodoushi terdiri atas 1) reru dan rareru, ini juga terbagi menjadi empat kelompok (ukemi, kanou, jihatsu, dan sonkei), 2) seru dan saseru (kausatif), 3) da dan desu (dantei = keputusan), 4) nai dan nu (uchikeshi = negatif), 5) ta (kako= bentuk lampau), 6) rashii (suitei 'anggapan/dugaan/perkiraan), 7) u, you, dan darou (suiryou 'perkiraan', ishi 'kemauan'), 8) mai (uchikeshi no suiryou = perkiraan negatif), 9) souda (denbun to youtai), 10) youda (tatoe 'perumpamaan', futashikana dantei 'keputusan yang tidak pasti'), 11) tai (kibou = harapan, keinginan), dan 12) masu (teinei $=$ halus). Kedua belas bentuk jodoushi di atas memiliki karakteristik masing- masing terkait pemakaiannya dalam konteks kalimat tertentu. Dari dua belas jenis jodoushi yang dijelaskan diatas, penulis tertarik untuk meneliti lebih dalam terkait jodoushi bentuk kanou, karena makna yang terkandung dalam kanoukei える (eru) dan れる (rareru) membentuk verba yang menyatakan kemampuan dan potensi mengenai seseorang atau suatu hal yang dapat dilakukan (Helina, 2009).

Menurut Sutedi (2007:115) Jodoushi bentuk kanou atau kanoukei adalah salah satu kata yang menyatakan kesanggupan untuk melakukan aktivitas atau pekerjaan. Sedangkan kanoubun merupakan kalimat yang di dalamnya terdapat jodoushi bentuk kanou atau kanoukei. Kanoubun merupakan kalimat yang menyatakan aktivitas, hal tersebut dapat dilihat dari dari kalimat 私は朝早く起きられる (watashi wa asa hayaku okirareru) yang berarti "saya dapat bangun pagi dengan cepat" (Sudjianto dan Dahidi, 2009 :175). Pada kalimat tersebut terdapat jodoushi bentuk kanou atau kanoukei, kata $i k u$ yang berarti "pergi" berubah menjadi ikareru yang berarti "dapat pergi”. 
Penelitian sebelumnya terkait kanoubun dilakukan oleh Kuswandi (2013) dala skripsi yang berjudul "Ungkapan Potensial V+koto ga dekiru dan eru/ rareru Dalam Mainichi Shinbun" yang hasil penelitiannya menemukan 31 data yang telah diklasifikasikan maknanya. Setelah data diklasifikasikan, diketahui bahwa secara makna dan penggunaan, ungkapan potensial dapat dikategorikan menjadi 2 kategori umum yaitu ungkapan potensial realisasi dan ungkapan potensial posibiliti. 2 kategori umum tersebut memiliki 15 sub kategori makna yang menjelaskan secara lebih rinci makna penggunaan ungkapan potensial. Mengenai perbedaan penggunaan antara ungkapan potensial $\mathrm{V}+$ koto ga dekiru dan $\sim$ eru/ rareru terdapat 5 faktorfaktor pembeda yaitu jumlah ketukan, ketentuan jenis verba, partikel penghubung dan sense. Faktor-faktor pembeda tersebt menyebab kan ungkapan potensial V+koto ga dekiru ada kala nya tidak bisa bersubtitusi dengan sempurna pada eru/ rareru.

Setelah membaca beberapa skripsi dan artikel mengenai penguasaan kanoukei dapat diketahui bahwa mahasiswa sulit menguasai kanoubun contohnya merubah verba ke bentuk kanoukei. Peneliti juga telah melakukan wawancara secara langsung mahasiswa tahun masuk 2018 Program Studi Pendidikan Bahasa Jepang Universitas Negeri Padang. Secara umum mahasiswa sulit menggunakan jodoushi, terutama bentuk kanoukei dalam kalimat. Peneliti juga telah mewawancarai salah seorang dosen terkait kanoubun dalam pembelajaran. Senada dengan pernyataan mahasiswa, dosen pengajar juga mengatakan, mahasiswa kurang menguasai penggunaan kanoukei dalam kalimat, menyebabkan mahasiswa kurang berani/percaya diri membuat kalimat. Untuk mengidentifikasi tingkat pemahaman mahasiswa mengenai kanoukei dibutuhkan penilaian secara khusus, akan tetapi berdasarkan hasil wawancara dengan dosen yang mengajar mata kuliah bunpo belum ada penilaian secara khusus yang terdokumentasi mengenai kanoukei.

Berdasarkan hal di atas, maka peneliti tertarik melakukan penelitian tentang penguasaan kanoukei..

\section{METODE PENELITIAN}

Jenis penelitian ini yaitu penelitian kuantitatif, karena data yang diteliti berupa angka-angka. Data dalam penelitian ini adalah nilai dari Penguasaan Kanoukei Mahasiswa Tahun Masuk 2018 Prodi Pendidikan Bahasa Jepang Universitas Negeri Padang. Metode penelitian yang digunakan dalam penelitian ini adalah metode deskriptif. Populasi dalam penelitian ini yaitu mahasiswa tahun masuk 2018 Prodi Pendidikan Bahasa Jepang Universitas Negeri Padang yang berjumlah 63 orang. Adapun sampel dalam penelitian ini yaitu sebanyak 30 orang. Teknik pengambilan sampel dalam penelitian ini yaitu menggunakan teknik random sampling. Teknik random merupakan teknik pengambilan anggota sampel dari populasi yang dilakukan secara acak tanpa memperhatikan strata yang ada dalam populasi tersebut.

Tes yang digunakan dalam penelitian ini berupa tes untuk penguasaan kanoukei mahasiswa tahun masuk 2018. Bentuk tes yang digunakan dalam penelitian ini adalah tipe tulisan berbentuk objektif. Dalam penelitian ini tes yang diberikan adalah tes isian singkat dan pilihan ganda.

Langkah pertama, mengubah skor menjadi nilai. Kedua, menafsirkan 
kemampuan kanoukei. Ketiga, mengklasifikasikan kemampuan kanoukei mahasiswa tahun masuk 2018 Pendidikan Bahasa Jepang Universitas Negeri Padang berdasarkan penggunaan skala 10 sesuai dengan sebaran nilai Universitas Negeri Padang. Keempat, membahas dan menyimpulkan hasil analisis.

\section{HASIL DAN PEMBAHASAN}

\section{Hasil}

Berdasarkan analisis terhadap skor tes, penguasaan kanoukei mahasiswa tahun masuk 2018 prodi pendidikan bahasa Jepang Universitas Negeri Padang sebagai berikut.

Tabel Nilai Rata-Rata Hasil Tes Penguasaan Kanoukei Mahasiswa Tahun Masuk 2018 Prodi Pendidikan Bahasa Jepang Universitas Negeri Padang

\begin{tabular}{|l|c|c|c|c|}
\hline & Nilai Max & Nilai Min & $\begin{array}{c}\text { Rata-Rata } \\
\text { (M) }\end{array}$ & Kualifikasi \\
\hline $\begin{array}{l}\text { penguasaan } \\
\text { kanoukei }\end{array}$ & 97 & 40 & 60,43 & $\begin{array}{c}\text { Lebih Dari } \\
\text { Cukup }\end{array}$ \\
\hline
\end{tabular}

Berdasarkan tabel di atas dapat diketahui nilai rata-rata penguasaan kanoukei mahasiswa yang diperoleh dari 30 orang mahasiswa adalah 60,43 dengan kualifikasi lebih dari cukup. Nilai tertinggi yang diperoleh mahasiswa adalah 97 dengan kualifikasi dengan pujian dan nilai terendah yang diperoleh mahasiswa adalah 40 dengan kurang.

\section{Pembahasan}

Sebagaimana telah dideskripsikan, hasil analisis data menunjukan secara keseluruhan kanoukei mahasiswa tahun masuk 2018 prodi pendidikan bahasa Jepang Universitas Negeri Padang dengan nilai rata-rata 60,43 dengan prediket 'Lebih Dari Cukup'.

Dalam penelitian ini, dapat diketahui penguasaan kanoukei mahasiswa dari tiga jenis indikator yang dinilai. Indikator tersebut adalah (1) mampu mengubah verba ke bentuk kanou, (2) mengidentifikasi partikel pada kanoukei, (3) mengidentifikasi kanoukei. Dalam penelitian ini diketahui tiga hal sebagai berikut.

Pertama, penguasaan kanoukei mahasiswa untuk indikator mampu mengubah verba ke bentuk kanou dengan nilai rata-rata 63,33. Nilai tertinggi yang diperoleh mahasiswa adalah 100. Dari nilai tersebut diketahui bahwa mahasiswa tersebut menguasai kanoukei dengan baik. Sementara nilai terendah yang diperoleh siswa adalah 30. Diketahui bahwa umumnya mahasiswa masih keliru menentukan kata kerja I dan kata kerja II dalam bahasa Jepang.

Kedua, untuk indikator mengidentifikasi partikel pada kanoukei dengan nilai rata-rata 57,33. Nilai tertinggi yang diperoleh mahasiswa adalah 90. Sementara nilai terendah yang diperoleh mahasiswa adalah 30 . Untuk mahasiswa yang mendapat 
nilai terendah pada indikator ini disebabkan karena mahasiswa tersebut kurang pemahaman akan penggunaan partikel dengan baik.

Ketiga, untuk indikator mengidentifikasi kanoukei dengan nilai rata-rata 61,67. Nilai tertinggi yang diperoleh mahasiswa adalah 100. Sementara nilai terendah yang diperoleh mahasiswa adalah 30. Nilai rendah yang diperoleh mahasiswa pada indikator ini yaitu dikarenakan mahasiswa salah memahami penggunaan partikel dan bentuk kata kerja I dan kata kerja II pada bahasa Jepang.

Berdasarkan pembahasan diatas, terlihat sekali bahwa penguasaan kanoukei mahasiswa masih kurang. Dari beberapa jawaban yang diberikan sampel penelitian, ada beberapa masalah yang ditemukan yaitu sebagai berikut :

Pertama, umumnya mereka memiliki kendala dalam membedakan bentuk kata kerja I dan kata kerja II .Kedua, kurangnya pengetahuan akan penggunaan partikel pada kalimat bahasa Jepang. Ketiga, kurangnya pemahaman akan perubahan bentuk pasif (kanoukei) dengan baik.

Dari keterangan di atas, pembelajar bahasa Jepang masih melakukan kesalahan yang umum ditemui khususnya pada pelajaran kata kerja bentuk pasif (kanoukei). Penguasaan kanoukei mahasiswa masih perlu ditingkatkan agar menjadi pada kategori baik

\section{KESIMPULAN}

Penelitian ini difokuskan untuk mengetahui penguasaan kanoukei mahasiswa tahun 2018 Universitas Negeri Padang. Diketahui berdasarkan tiga indikator. Indikator tersebut adalah (1) mampu mengubah verba ke bentuk kanou, (2) mengidentifikasi partikel pada kanoukei, (3) mengidentifikasi kanoukei.

Berdasarkan hasil analisis data yang telah diuraikan pada bab IV, dapat disimpulkan lima hal sebagai berikut. Pertama, penguasaan kanoukei mahasiswa secara umum dengan nilai rata-rata 60,43. Kedua,dari ketiga indikator yang telah diujikan, dapat disimpulkan bahwa penguasaan kanoukei mahasiswa yang terkuat terdapat pada indikator mampu mengubah verba ke bentuk kanou dengan nilai ratarata 63,33, sedangkan yang terlemah terdapat pada indikator mengidentifikasi partikel pada kanoukei dengan nilai rata-rata 57,33. Ketiga, umumnya mereka memiliki kendala dalam membedakan bentuk kata kerja I dan kata kerja II. Keempat, pengetahuan akan penggunaan partikel pada kalimat bahasa Jepang. Kelima, kurangnya pemahaman akan perubahan bentuk pasif (kanoukei) dengan baik.

\section{REFERENSI}

\section{Abdurahman dan Ellya Ratna.2003." Evaluasi Pembelajaran Bahasa dan Sastra} Indonesia". Bahan Ajar. Padang: FBSS UNP.

Djiwandono, Soenardi. 2008. Tes Bahasa Pegangan Bagi Bahasa Jepang. Jakarta : Indeks.

Helina. 2009. Analisis Bentuk Kemungkinan Bentuk Kanoukei eru Dalam Kalimat Bahasa Jepang (Kajian Morfosintaksis dan Semantik. Jurnal. Universitas Kristen Maranatha.

Iori, Isao. 2000. Nihongo Bunpo Hando Bukku. Tokyo. 
Lidra, Harviko dan Anggia Putri, Meira dan Yani, Damai. 2018. "Kemampuan Penggunaan Jodoshi Souda Pada Mahasiswa Tingkat III Pendidikan Bahasa Jepang Universitas Negeri Padang". Jurnal Omiyage. Volume 1 No. 3.

Margono. 2010. Metodologi Penelitian Pendidikan. Jakarta : Rineka Cipta.

Noorsanti. 2017. Diatesis (Tai) Dalam Bahasa Jepang (Tinjauan Dala Buku Minna No Nihongo). Journal of unesa. Universitas Negeri Surabaya.

Purba. dkk. 2013. Pembentukan Verba Potensial Dalam Kalimat Bahasa Indonesia Dan Bahasa Jepang (Suatu Kajian Morfologis). Jurnal. Universitas padjajaran.

Sudjianto dan Dahidi. 2009. Pengantar Linguistik Bahasa Jepang. Jakarta: Kesaint Blanc.

Sutedi, Dedi. 2007. Nihongo no Bunpou. Bandung : Humaniora 